Journal of Economics and Behavioral Studies

Vol. 6, No. 8, pp. 616-624, August 2014 (ISSN: 2220-6140)

\title{
Local Economic Development: A Conceptual Re-Articulation
}

\author{
Sebeka Richard Plaatjie \\ University of South Africa, Republic of South Africa \\ plaatsr@unisa.ac.za
}

\begin{abstract}
Local economic development (LED) in the context of the development question is generally celebrated as a silver bullet to development challenges in Africa. However this discourse is more complex and needs greater theoretical scrutiny in order to understand its meaning. This paper picks up standpoint theory to critique the dominant understanding/s of local economic development and argues that unless it is more people-centered and benefits the local human/s, local economic development will remain an imposition from the top which will continue to alienate the local human and will remain an imperial project.
\end{abstract}

Keywords: Local economic development, development, epistemology, tourism, decoloniality

\section{Introduction}

'A system of domination and exploitation that operates on a world-scale such as the capitalist worldsystem cannot have a "national solution". A global problem cannot be solved at the nation-state level' (Grosfoguel, 2011, p. 31).

Local economic development (LED) in the context of the development question is generally celebrated as a silver bullet to development challenges, particularly of those in Africa. However the LED discourse is more complex and needs greater theoretical scrutiny in order to understand its real meaning today. For example, many scholars and development practitioners tend to dislocate LED from the broader global modern capitalist world system and its attendant discourses of development. Others understand it more instrumentally, dislocating it from the sociology of African political history. These approaches accept LED as a panacea and reduce its understanding to either technical or economic categories and as both at best, often without problematising it within the broader complexities in Africa. In the Wretched of the Earth, (Fanon, trans.1961) points to multiple socio-economic and political issues that continue to define postcolonial Africa. He writes about how the legacy of colonialism will continue to define postcolonial Africa in ways that maintain the empire-colony asymmetrical relation in order. That is the supremacy of the empire over the colony in any form of imagination which is facilitated today by coloniality ${ }^{i}$

It is against this background that this article is an attempt to understand the meaning of LED in Africa from a world systems analysis and the broader complexities and dichotomies of the development discourse and the postcolonial situation in Africa. This is because LED in the context of Africa cannot be fully understood without understanding the global power relations between the core and peripheryii Furthermore, LED can also not be fully understood without the knowledge of the historical conditions and motives that gave rise to it, including those that facilitated its manifestation in the past and those that continue to do so in the present. This exercise attempts not only to explain coloniality in LED, but also to reveal the irony of LED in promising development yet purposefully under-developing those in the periphery of what Grosfoguel (2011) chooses to call a 'Capitalist/Patriarchal Western-centric/Christian-centric Modern/Colonial World System' (p. 13). That is a world system that uses race or racism as an organizing principle for creating multiple global hierarchies sexual, political, epistemic, economic, spiritual, and linguistic - of the European/non-European divide and which rearranges every other global power structure $(2011$, p. 8). For example, spiritual hierarchies would privilege Christianity and place it at the very top and other religions such as Islam, Buddhism and various African religions would be placed at the bottom in a cascading scale of 'their' ontological density - a density predicated on proximity to Europeanness (2011). 
The first section of the article foregrounds theoretically the logic of LED by tracing its genealogy to modernity. The second section looks at the structure and nature of the postcolonial state, including the global capitalist world system. This part reflects on how the two interact as well as on the continuities and discontinuities of the past (colonial) into the present (postcolonial). Some alternative perspectives are also provided. This section also reflects on how the LED is a continuity of the past (imperialism) now in synergy with the global capitalist system to entrench coloniality. A conclusion and recommendations follow after this.

\section{Development: What is development?}

Development or development discourse is very often understood to have emerged in the late 1940s (Rist, 1997) after the Second World War. Many scholars argue this point because this period presented a post-war era which necessitated the development of Europe following the devastating effects of the war. This development ethos was expressed more fully by the formation of the United Nations and in 1948 with the inaugural speech of the US president, Harry Truman calling for an end to war and agitating for a developmental trajectory. Furthermore some scholars also argue that the 1940s marked the genesis of development because of the constitution of the United Nations which signaled, for the first time, a commitment to global unity and the development of humanity. However, some authors trace the genesis of development much further in history to the emergence of the Cartesian subject in the $16^{\text {th }}$ century, and some go even much further back to the cradle of humanity. These scholars, particularly the latter, understand the discourse of development to have begun ever since humanity and a search for self-improvement or selfdevelopment became part of mankind. These almost competing versions on the origins of development or development discourse brings us to the question which Cesaire (Trans, 1972) put across in trying to understand what colonialism was about. The question that also needs to be raised in the context of development is: What, fundamentally, is development?

In an article entitled Beyond Western-centric and Eurocentric development: A case for decolonizing development (Plaatjie, 2013), we have made some observation about the way in which truth, ideology and development intersect to demonstrate just how development is a product of a particular truth which becomes facilitated by an ideology into the everyday living of the people who experience and understand it. We have done this as an attempt to reveal the relativity of truth and thus of development and to affirm Grosfoguel's (2011) idea of dismissing Eurocentric fundamentalist arguments that there is only one tradition from which to achieve truth and universality. Zein-Elabdin (as cited in Keita, 2011) also confirms the particularism of development and emphasizes this point thus:

development is a philosophical question; it is part of a total cosmology rooted in metaphysical assumptions ... it is ultimately a question of social meaning - or collective understanding of purpose; therefore making it futile to attempt a substantial challenge to it without first treading the philosophical and cultural grounds on which it firmly rests (p. 217).

It is for this reason that development or truth should not be understood in universal terms as it is commonly projected by Western philosophy (Grosfoguel, 2011), but as a development or truth that is predicated on the relativities, subjectivities and cosmologies of those who define, live and give meaning to it (Alcoff, 2008; Wynter,1991, p. 253).

However, notwithstanding the potential richness of pluriversal as opposed to universal conceptions of development, these experiences have been submerged under the Eurocentric experience alone. In simple terms, this means that there is only one position or reality - which is European - from which development can be authentically defined. It is against this background that Mitchelle (as cited in Lushaba, 2009) stated that:

the modern age presents a particular view of geography, in which the world has a singular center, Europe ... that imagines itself a continent in reference to which all other regions are to be located; and an understanding of history in which there is only one unfolding time, the history of the West, in reference to which all other histories must establish and receive their meaning (p.13). 
The hegemony of the West has come to define development on its own to the exclusion of others and violently enforced this conception through colonialism as universally resonant to all humanity (Dussel, 1998; Escobar, 2004). Ndlovu-Gatsheni(2013) argues that the conception of this Eurocentric development is one which pathologises the subalterns as inherently suffering from a series of lacks (lacking substance, lacking rationality, lacking being, lacking souls, lacking history, lacking writing, lacking civilization, lacking development, lacking democracy, and lacking human rights) which need to be corrected. Wynter (as cited in Keita, 2011) qualifies this claim even more in the following words:

To aim at development requires not yet being developed. To be developed implies achieving more than an end but an end that ought to be achieved. In terms of an organism, the obvious example is maturation of that organism or its achievement of its adult form. Implicit in not being developed, then, is a condition of childhood at worst and adolescence at best, but in neither instance is there the full responsibility - namely, adulthood. Without responsibility, there is no agency, and without agency, the familiar pattern of dependence follows ( $p$ 73).

Fundamentally this conception of development is one which hastens the subalterns to catch up with the West and to assimilate their ways of life by force and coercion. It is for this reason that Escobar $(2004,213)$ also adds that 'through the management of specialized violence, territorial control, sub-contracted massacres, and cruel little wars', neo-liberal capitalist project is entrenched and necessitates Western modernity as an antidote to the pathology of the subalterns in the periphery. Grosfoguel (2011) more bluntly confirms that violence and coercion were used to modernize the subalterns:

During the last 510 years of the Capitalist/Patriarchal Western-centric/Christian-centric Modern/Colonial World-System we went from the $16^{\text {th }}$ Century Christianize or I shoot you, to the $19^{\text {th }}$ Century civilize or I shoot you, to $20^{\text {th }}$ Century develop or I shoot you, to the late $20^{\text {th }}$ Century neoliberalize or I shoot you, and to the early $21^{\text {st }}$ century democratize or I shoot you (p. 28).

Throughout each of these stages which were meant to have brought development for the childlike subalterns, the subalterns remained captivated by the rhetoric of development which for Cesaire (1972) is a system which fails not only to lift thousands out of poverty, but also to solve its own problems. Many authors argue that while the rhetoric of development promised progress and support through philanthropic organizations such as the World Bank and the International Monetary fund (IMF), subalterns continued to suffer to this day.

In The Wretched of the Earth, (Fanon, trans. 1961) depicts how the conquered were robbed of their humanity and debased from their ontological identities and left to languish in the zone of non-being. Dussel (2002) also explains how traditions and cultures of the conquered were destroyed and families ripped apart through slavery. Moreover, whole knowledge systems were buried under the rubble of destroyed shrines (Cesaire, 1972; Dussel, 2002; Mbembe, 2002). Some observers recount how millions of Africans suffered under the IMF's structural adjustment programs, and how these multitudes continue to suffer today from exploitation in the sweatshops of the modern global racial-capitalist democratic system. It is therefore on the basis of the violence of colonialism - destruction of subaltern knowledge systems, suppression of the subaltern voices and discourses facilitating self-hate - which Europe managed to assert itself as the only authentic universal authority to define and to give meaning to life. It is thus no surprise that the rest of the former colonies in Africa have become a replica of Europe in all forms of social-economic and political existence to embrace Euro-American modernity.

\section{The post colony and development}

With the demise of colonialism starting more or less in the 1950s many former African colonies became sovereign states with the exception of South Africa which went through colonialism and apartheid before democratic rule in 1994. This period marked the victory of the African nationalist struggle over colonialism. However, Grosfoguel (2011) points out that this victory was only a juridical one. It was a victory which only

allowed the Africans to manage the state but did not lead to decolonization. He stresses that the end of colonialism did not mean the end of a 'Capitalist/Patriarchal Western-centric/Christian-centric 
Modern/Colonial World System' (2011, p. 13) but an end to direct colonial administration of the colony by the metropole. The world structure and system remained firmly unchanged because of colonial matrices of power, which through coloniality continues to this day to maintain the core-periphery relations firmly entrenched.

Amin (1997, p. 5) lists monopolies of technology, financial monopolies of world markets, monopolies of control over natural resources, media and weapons of mass destruction as constitutive of the power matrix of the West. However, Quijano (1997) has a more exhaustive description of the colonial matrices of power. He states that this power matrix is constituted by four interrelated domains: the control of the economy (land appropriation, exploitation of labor, control of natural resources; control of authority, institutions and army); control of gender and sexuality (family) and control of subjectivity and knowledge (epistemology, education and formation of subjectivity). This global power matrix further complicates challenges of the development of Africa, particularly the postcolonial phase.

Many scholars such as Fanon (1961); Amin (1974, 2011); Mamdani (1996); Mbembe (2002); Mkandawire (2005); Ndlovu-Gatsheni (2011) and many more have contributed in various ways towards understanding the challenges of the postcolony in Africa. For example, Fanon (1961) wrote about the dialectic facing the postcolonial political elite at independence which is still relevant today: they are still seeking assistance from the same structures they want to break away from, and this is how he puts it: The national middle class which takes over power at the end of the colonial regime is an under-developed middle class. It has practically no economic power, and in any case it is in no way commensurate with the bourgeoisie of the mother country which it hopes to replace. In its willful narcissism, the national middle class is easily convinced that it can advantageously replace the middle class of the mother country. But that same independence which literally drives it into a corner will give rise within its ranks to catastrophic reactions, and will oblige it to send out frenzied appeals for help to the former mother country (Fanon 1961, p120).

Fanon (1961) also spoke about how the political elite who emerge after independence become the intermediary between the postcolony and the metropole. For Gordon (2011, p. 71), these third world elites become agents and accomplices to the neocolonial situation. This point is qualified by Gendzier (as cited in Gordon 2011, p. 75) who comments that in the name of Africa's development, neocolonialism regains its strength through the ruling elite and technocrats - lumpen bourgeoisie - who work within and maintain the colonial status quo while promising to change it invoking what Fanon (1961) calls repetition without change: a zero-sum game which facilitates continuity of the colonial past into the present.

The dependency school of thought and Marxists alike have also demonstrated in various ways how the nature and structure of the global political economy favors the core to the detriment of the periphery. Amin (1974, 2011) and Saul (1974) explain how the structure of the global capitalist system is ontologically parasitically dependent on the existence of capitalisms $\mathrm{s}^{\mathrm{iii}}$ in the periphery to the benefit of the core. The former cannot survive without the latter. Amin (1974) states that these periphery capitalisms are not meant to develop into anything substantial or similar to the global capitalist system in the west, but are meant only to serve as fodder to sustain the global racial-capitalist system of the metropole. It is therefore no surprise that African states trade the least amongst themselves, that they import more than they export, that they spent approximately 14 billion US dollars annually on debt servicing and that they are permanently fixated in the periphery of the global capitalist political economy of a racially designed world system (Amin, 1974; Grosfoguel, 2011). This view resonates with that of some observers that the manifestation of poverty and underdevelopment in Africa is thus not a consequence of a mistake/s (Girvan, 2008), but of a deliberate wellorchestrated process systematically engineered to keep the colony fixated in poverty and underdeveloped. This deliberate underdevelopment of the periphery is further qualified by Eric Williams as cited in Girvan (2008) that we consume what we do not produce and produce what we do not consume.

This dichotomy is one which Amin (1974) thinks is also a result of a monopoly which increases the propensity of the subalterns to want imported goods, and which permanently locks the periphery into childlike economies with no hope for maturation. It is for this reason that Zeleza $(2010$, p. 8) also concludes that economically, colonialism left behind underdeveloped economies which are externally dependent. In simple terms this means that the global system is constitutive of the periphery, which reminds us of 
Grosfoguel's (2011) assertion that notwithstanding the potentiality of a nation-state to contribute towards long term transformation of the world system, global problems cannot have national solution.

Ndlovu-Gatsheni (2011) and Young (2012) also write about the political elites of the postcolonial state. These scholars explain how through the rhetoric of nationalist discourses the political elites reproduce violence to sustain their privileged status and to suppress the people. Ndlovu-Gatsheni (2011) writes that whereas colonialism employed violence - slavery, dispossession, killing, rape and imprisonment - to modernize the colonized, African nationalism reproduced colonial violence and authoritarianism, now in the name of national unity, security and development. It is from these manifestations reminiscent of the colonial - era including the state structure and imposed political borders - that we see continuities of the colonial into the postcolonial. It is with regard to such continuities that Young (2012) concludes on the postcolonial state that 'a genetic code of the new states of Africa was already imprinted on its embryo within the womb of the African colonial state' (p. 336). It is for this reason that Zeleza (2010) also comments that 'the colonial state was the midwife of colonial capitalism' (p. 4). What this effectively means is that technically, we cannot refer to African states as having transcended colonialism because of the continuation of the past into the present.

\section{Local economic development, the world systems analysis and development in the postcolony}

It is now clearer from the preceding section that in the context of Africa LED could be read within the prevailing racial hierarchical structure of the world system and the postcolonial condition as well as within the broader logic of development. The latter refers to Western conceptions of development - modernity, the Washington and post-Washington consensus framework amongst others. More fundamental and particularly at this stage, is that this conception of development is one predicated on neoliberal notions of development or progress such as wealth, materialism and the development nexus.

Leal as cited in Cornwell and Eade, (2010, p. 90), makes an interesting observation about the discourse of development. He observes that starting in the European medieval era to date the development discourse has had a remarkable ability to deploy rhetoric for self-preservation whenever it is under moral attack in order to delegitimize itself. Leal further argues that this explains why we have seen over the past 50 years, successive trends in the discourse of development such as community development, basic human needs, and rural development, sustainable development and participatory development; and capacity building, human rights and good governance in the twenty first century'. The rhetoric of LED is the most recent of such rhetorical tactics. The rhetoric of LED is thus deployed to perpetuate the prevailing status quo and to conceal the irony and failure of development in the $20^{\text {th }}$ century. Leal adds that the use of these morally appealing words in development such as community, basic needs and sustainable development for example have a zombifiying effect on the poor and makes them believe that change has or will take place while there is nothing taking place at all and the dire conditions of the periphery remain the same if they have not become worse.

At the heart of the LED discourse, first, is the fallacious and reductionist assumption that the challenges of the periphery are only economical. Secondly, is the assumption that local interventions, particularly LED, can resolve global challenges that are of an entire global world system which is 'Capitalist/Patriarchal Western centric/Christian-centric Modern/Colonial World System' (p. 13). The fundamental question then becomes; can local solutions solve global problems? It is these fallacious and misleading ambitions of the LED discourse which allows many scholars and politicians alike to push for the idea of LED as a possible solution to the challenges of the periphery. Predicated on the discredited Rostovian thesis of economy and development nexus and the trickle-down theory, this illogicality suggests that achievement of LED alone will lead to the development of subalterns. That is the myth that says; through the success of local economy the subalterns can restore their dignity and ontological identity, that they can restore their epistemologies, aesthetics, languages, religions, cultures and traditions including their cosmologies and mythologies and most important in the context sketched in this article, is that through LED, the subalterns can define and live their own development and truths without any interruption.

While LED may indeed lead to improvement of lives for a few in periphery capitalisms, this would be a development or an improvement of lives in the periphery but not a development or an improvement of lives in the core. For the former, this development is within the narrow constraints of periphery capitalisms and is 
more survivalist. At best, this type of development can lead to the emergence of a small politically connected bureaucratic petite bourgeoisie class. From a world system analysis and by no means discrediting progressive forces within this particular class, Fanon (Trans, 1961) states that this class is bankrupt, powerless, ineffective and potentially counterproductive.

Nonetheless, proponents of LED saw it first more in a technicist fashion of cause and effect, and equated wealth with development (Blakely and Leigh, 2010). After a serious critique of the LED discourse which effectively discredited its growth and development, and its trickle-down theory, this discourse has tried to relegitimize itself. At its best, recent conceptions of LED combined recycled rhetoric of earlier paradigms sustainable development, meeting basic needs of people and reducing inequalities - and in cooperating these into the new vision of LED. That is LED as a process offering an opportunity to local government, the private sector, the non-profit sector and the local community to work together to enhance competitiveness and thus encourage sustainable growth that is inclusive (Department of Provincial and Local Government (DPLG), 2006-2011).

Blakely and Leigh (2010) also contributed to this revised vision of LED and state that LED can be achieved when a community's standard of living can be preserved and increased through a process of human and physical development that is based on principles of equity and sustainability. These authors argue that this new vision of LED offers a pathway to a sustainable local economic development through - job creation that provides living wage, consumption of better goods and services, and quality housing, reducing inequality between demographic groups (age, gender, race, and ethnicity) and to maintain sustainability of resources and the environment - that focuses on the desired ends state rather than growth-defined objectives (2010). Nonetheless, this new and improved articulation of (LED) is still suspiciously mum on issues of global social justice.

Perhaps even more troubling with the revised articulation of LED is the emphasis of territoriality and its strategic utility. This means that LED is a process that can be led by various economic sectors - agriculture, mining, tourism and many others depending on the competitive edge of a particular territory. In simple terms, this logic means that spatiality, as opposed to people, largely determines the nature of LED in any given territory. This logic is problematic at many levels because what may appear as strategically useful for LED may not necessarily be in synergy with the values and cultural ethics and religious beliefs of communities inhabiting those territories. Lessem and Schiefer's (2010) integral economic theory highlights the centrality of a systematic balance of culture and spirituality; religion and humanity; nature and community; science and technology including finance and enterprise as catalysts to any form of meaningful development. These scholars argue that the sustainability of any living organism, be it a state, law or economy, depends on a dynamic balance of the above mentioned four mutually reinforcing and interdependent components. Lessem and Schiefer insist that this integral perspective is applicable to all types of social systems, from the individual to the organizational, from community to society. For example, on an individual level, this approach would seek a dynamic balance between heart, spirit, mind and soul. This means that the conceptions and practices of LED ought to be responsive to humanity and religion, the natural environment and community, cultures and traditions and epistemology (science and technology), including the finance and enterprise of the people inhabiting those spaces. In simple terms, this conception and application of LED is one which privileges the local human more than the space they inhabit alone as is the case with traditional conceptions and practices of LED. The futility of prevailing conception and practices of LED is demonstrated in brief below.

While there are many possible economic activities that can lead LED programs, I chose to look specifically at the tourism-led LED programs, particularly the industry of eco-tourism to qualify some points I have made earlier. I have chosen the tourism sector because the tourism industry is currently said to be the fastest growing development sector in Africa, particularly in rural areas where it represents the principal source of income (Adamou and Clerides, 2009; Matarrita-Cascante, 2010). Scholars and proponents of tourism-led LED programs have variously documented how tourism has contributed to job creation and improved livelihoods in communities and rural communities in particular. More of these scholars recount how tourism in the absence of alternative economic activity provides the only source of economic "hope" for people who otherwise would have "nothing" to hold onto. 
However, the very little that the proceeds of tourism jobs fetch for the local communities must be understood within Amin's warning of its futility in relation to the politics of world capitalism because of the propensity of these proceeds to be used for imported goods. It must also be noted that while the rhetoric of LED and ecotourism promises jobs and improved lives, at the same time it takes away independent survival strategies and resources of subaltern communities and make them food-insecure and dependent on the insecure labor industry. As Fanon (trans. 1961) noted, this process is facilitated by the newly emerged bureaucratic petite bourgeoisie capitalist political classes. For example, we have heard too often how in the name of ecotourism the postcolonial state in service of the metropole displaced thousands from their lands and how, in the process, indigenous development programs based on respect for customary land rights and cultural practices have been trampled and interrupted in the name of LED and job creation (Neumann, 1995).

The case of wildlife conservation and the emergence and growth of the mass tourism industry in Tanzania sheds more light on this dichotomy. Neumann (1995) recounts how, in the wake of independence, tourism became Tanzania's fastest growing industry expanding by 600 per cent from 1985 to 1990 . He further documents how the state, in collaboration with the International Union for Conservation of Nature and Natural Resources (IUCN, now called the World Conservation Union) fast-tracked this venture and how, in the process, the pastoralist society of the Masai suffered loss of prime grazing lands to wildlife conservation. Neumann also illustrates how this practice continued when the Masai pastoralists were forced out of the Nkomazi Game reserve in 1988, after refusing to obey a government eviction order (1995). Neumann (1995) insists that the infusion of foreign capital in tourism resulted in a French hotel chain Accor/Novotel becoming state partners for the management of hotels and lodges, including the main facilities in the Ngorongoro Conservation Area and the Lake Manyara and Serengeti National Parks. He concludes that notwithstanding the profit that tourism brings, particularly for the political classes, and the number of jobs this industry creates for a few in the communities, pastoralist communities remain displaced from their land and places of worship and their livelihood or survival strategies are interrupted only to make them vulnerable.

In the South African part of the Kgalagadi Transfrontier Park, the Khomani San face the same ordeal of being forcibly removed from the park (Schoon, 2007). Additionally, Schoon states that the Kruger National Park continues to negotiate several land claims with dislocated and vulnerable communities previously displaced in the creation of the park (2007). More recently we have learnt how the Botswana government continues to molest the Kalahari Bushmen through hunting restriction and denial of water supply including forced evictions from the Central Kalahari Game Reserve - their land - for mining, and as government puts it; "to give primitive Bushmen access to the benefits of civilization, such as medical care and education" (Bookers Christopher 2013).

It is against this background that we have argued that to understand LED as a territorial and or economic matter alone to the exclusion of the peoples inhabiting these spaces - their epistemologies, cosmologies, ethics, religious beliefs and cultural practices, technologies and livelihoods - amounts to nothing more than an imposition and an imperial project. It is no surprise that the tourism industry in Tanzania has rode roughshod over every other consideration of what the Masai could consider for themselves to be LED in the land on which they have subsisted for centuries and from which they are being forcefully removed today.

\section{Conclusion}

This article demonstrates that development is a relative concept which is predicated on one's own truth and cosmology. However, this article also points that notwithstanding its relativity, the concept of development and the entire discourse that has crystallized around it is firmly encored only in Euro-American cosmology, which is modernity and which has been historically enforced onto the periphery through violence and continues today to be enforced through coloniality. The article also demonstrates the irony of the discourse of development, that it promises development for the periphery but yet systematically under develops it. We have also concluded that race or racism at the global scale is a motivating factor of the exploitation of the periphery by the core. The article reflects on the very discourse of LED and finds that the rhetoric of LED perpetuates and entrenches Western ideas of development. This is because the prevailing view of LED is still locked within modernity and essentialisms economics and spatiality - to the exclusion of the people - their cultural values, religions, ethics, epistemologies and technologies - inhabiting those spaces. This point is made 
more explicit through tourism led LED in Tanzania where in the name of LED the pastoralist community of Masai have lost their land - places of worship, economic activity - and made dependent on their labor. In this context it is clear that LED did not bring development but militated against the livelihoods of the people at whom development was aimed.

The latter conception of LED assumes the challenges of the periphery to be only economic and discount those constituted by colonialism - loss of identity, epistemology, the discourses of self-hate and the challenge of the postcolonial political elites - and the complex nature of a 'Capitalist/Patriarchal Western centric/Christiancentric Modern/Colonial World-System' Grosfoguel (2011, p. 13). Furthermore, inherent in this conception of LED is the misconception that there can be local solutions to challenges of the unfair racially constructed world system. With these challenges it clear that we need a much broader systemic approach which will challenge the entire cosmology upon which the entire discourse of development and LED is predicated and which will ultimately lead to a racially unstratified world system and the ecology of all human existence. Such a task will require what Quijano (1997) calls socialization of power. That is a socialization of power in a way that does not privilege the state as the sole authority of power - because of its propensity to collude with the metropole in ways that sustain parasitic relations of the core on the periphery - but also privileges ordinary people and communities to adjudicate over their issues and to decide their fate. This should include giving their own meaning to concepts such as development, democracy, human rights and more particularly to LED. In the context of the economy or economics this approach would require communities to use their own resources in ways that unlock their ingenuity and affirm their humanity. In simple terms, this conception and application of LED would be one which would privilege the local human and his immediate existential conditions. Should it fail, LED will remain a glorified imperial project!

\section{Notes}

iMaldonado-Torres differentiates colonialism and coloniality as follows: 'While the former (colonialism) denotes a political and economical relation in which the sovereignty of a nation or a people rests on the power of another nation, which makes such a nation and empire (coloniality) instead, refers to long-standing patterns of power that emerged as a result of colonialism, but that define culture, labor, intersubjective relations, and knowledge production well beyond the strict limits of colonial administration.' Coloniality survives colonialism.

ii Core-periphery denotes the relation between the colonizers and the colonized, where the 'core' represents the colonizing states which are also called the 'metropole' and the periphery represent the colonized countries and those which fall outside the hegemony of the colonizing countries.

iii Samir Amin (1974) speaks of capitalist systems existing at different levels in the global political economy. Here, Capitalisms refer to other capitalist economies existing in the periphery and which are not as fully developed as those capitalist economies in the west.

\section{References}

Adamou, A. \& Clerides, S. (2009). Prospects and Limits of Tourism-Led Growth: The International Evidence. Cyprus: The Rimini Centre for Economic Analysis.

Alcoff, L. M. (2008). Immanent Truth. Science in Context, 10(1), 97-112.

Amin, S. (1974). Accumulation on a World Scale: A critique of the Theory of Underdevelopment, Sussex, England: The Harvester Press.

Amin, S. (1997). Capitalism in The Age of Globalization: The management of contemporary society, London \& New Jersey: Zed books

Amin, S. (2011). Ending the Crisis of Capitalism or Ending Capitalism? Dakar: Pambazuka Press, Codesria.

Blakely, E. J. \& Leigh, N. G. (2010). Planning Local Economic Development: Theory and Practice. Los Angeles: Sage

Booker, C. (2013). Botswana is persecuting its Kalahari Bushmen and we had a role in it: Already evicted, tortured and deprived of water, the Bushmen face devastating new restrictions. The Spectator Magazine.

Cesaire, A. (1972). Discourse on colonialism. (J. Pankham, Trans.): New York and London: Monthly Review Press.

De Sousa Santos, B. (2006). Beyond Abyssal Thinking: from global lines to ecology of Knowledge, Paper presented at the Fernand Braudel Center, University of New York, Bringhamton. 
Department of Provincial and Local Government, (2006-2011). National Framework for Local Economic Development in South Africa, Republic of South Africa.

Dussel, E. (1998). Beyond Eurocentrism: The World-System and the Limits of Modernity. In F. Jameson and M. Miyoshi (Ed.).The Cultures of Globalization (p. 3- 31). Durham, NC: Duke University Press.

Dussel, E. (2002). World System and Trans-Modernity. Nepantla: Views from South, 3(2), 221-244.

Escobar, A. (2004). Beyond the Third World: Imperial Globality, Global Coloniality, and Anti-Globalization Social Movements. Third World Quarterly, 25(1), 207-230.

Fanon, F. (1961). The Wretched of the Earth. (C. Farrington, Trans.). New York: Penguin Books.

Girvan, N. (2008). The Postcolonial Economy and Society: Facing the Challenge. Paper presented at St Vincent and the Grenadines.

Gordon, L. R. (2011). Fanon and Development. In L. Keita (Ed.), Philosophy and African Development: Theory and practice (pp. 69-85). Dakar: Codesria.

Grosfoguel, R. (2011). Decolonizing Post-Colonial Studies and Paradigms of Political Economy: Transmodernity, Decolonial Thinking, and Global Coloniality. Transmodernity: Journal of Peripheral Cultural Production of the Luso-HispancWorld, 1(1), 1-38.

Keita, L. (2011). Philosophy and African Development: theory and Practice. Dakar: Codesria.

Leal, P. A. (2010). Participation: the ascendency of buzzwords in neo-liberal era. In A. Cornwall and D. Eade (eds.), Deconstructing Development Discourse: Buzzwords and Fuzzwords. Oxford: Practical Action Publishing, Oxfam.

Lessem, R. \& Schieffer, A. (2010). Integral economics: Releasing the Economic Genius of Your Society. Farnham, Surrey, England: Gower publishing.

Lushaba, L. W. (2009). Development as Modernity, Modernity as Development. Dakar: Codesria.

Mamdani, M. (1996). Citizen and Subject: Contemporary Africa and the Legacy of Late Colonialism. Princeton: Princeton University Press

Matarrita-Cascante, D. (2010). Beyond Growth: Reaching Tourism-Led Development. Annals of Tourism Research, 37(4), 1141-1163.

Mbembe, A. (2002). African Modes of Self-Writing. Public Culture, 14(1), 239-273.

Mkandawire, T. (2005). African Intellectuals: Rethinking Politics, Language, Gender and Development. Dakar: Codesria Books.

Neumann, R. P. (1995). Local Challenges to Global Agendas: Conservation, Economic Liberalization and the Pastoralists' Rights Movement. Antipode, 27(4), 363 - 382

Ndlovu-Gatsheni, S. J. (2011). The Logic of Violence in Africa. In Karl Hack The Ferguson Centre for African and Asian Studies. The Open University Walton Hall Milton Keynes MK7 6AA

Ndlovu-Gatsheni, S. J. (2013). Empire Global Coloniality and African Subjectivity. New York: Berghan Books.

Plaatjie, S. R. (2011). Beyond Western-centric and Eurocentric development: A case for decolonizing development. Africanus, 43(2), 118-130.

Quijano, A. (1997). Colonialidad del poder, cultura y conocimiento en América Latina. Anuario: Mariateguiano, 9: 113-122. In V. Adreotti, (n.d). Engaging (geo) political economy of knowledge construction: towards decoloniality in global citizenship, School of Maori, Social and Cultural Studies in Education. Working Paper. Aotearoa: University of Canterbury.

Rist, G. (1997). The History of Development: From Western Origins to Global Faith. London and New York: Zed Books.

Schoon, M. J. (2007). Building Robustness to Disturbance: Governance in Southern African Peace Parks. Paper presented at the Parks, Peace, and Partnership Conference, Waterton, Canada.

Wynter, S. (1991). Columbus and the Poetics of the Propter Nos. Annals of Scholarship, 8(2), 251-286.

Young, C. (2012). The postcolonial state in Africa: Fifty years of independence, 1960-2010. London: University of Wisconsin Press.

Zein-Elabdin, E. O. (2011). Postcoloniality and Development: Development as a colonial discourse. In L. Keita (Ed.), Philosophy and African Development: Theory and practice (pp. 215-230). Dakar: Codesria.

Zeleza, P. T. (2010). The Developmental and Democratic Challenges of Postcolonial Kenya. Paper presented at James, S. Memorial Lecture Series, Bellarmine College of Liberal Arts, Loyola Marymount University: Los Angeles, California. 